Photo-Electronic Image Devices

Proceedings of the Second Symposium held at Imperial College, London, September 5-8, 1961. Edited by J. D. MeGee, W. L. Wilcock and L. Mandel. (Advances in Electronics and Electron Physics, Vol. 16.) Pp. $x v+654$. (New York and London: Academic Press, 1962.) $130 s$.

A DVANCES in photo-electronics have largely contred around image devicos, photomultipliers and other components for converting radiation into electronic signals. The spur to increase sensitivity, signal/noise ratio and spatial resolution and to improve reproducibility has kept technologists busy and has led to excursions into allied branches of applied physics, particularly olectron optics and vacuum technology. The discovery of now physical offocts likely to have far-reaching influence is not at present a primary aim of the subject, which, howover, does not lack effects requiring clarification and justification on fundamental grounds. If the subject is compact, that is more than can be said of the workers in it, many of whom owe their first allegiance to particular fields of application. Prof. McGeo, in organizing two symposia on the key-imago devices, has thereby brought together scientists who might otherwise never have met.

The report on the second symposium on "PhotoElectronic Image Deviccs", held at the Imporial College of Science and Technology during September 5-8, 1961, is very factual; it shows no diminution of activity since tho 1958 symposium, stresses the attention being directed to details to improve performance and leaves no doubt as to the contributions being mado by users (compare the transistor, for which no user has also beon a designer or technologist). Several astronomers are now using electronic cameras following pioneering work by Lallomand, Duchesne and a few othors. The precautions needed to prevent the photographic plate spoiling the vacuum and hence the photocathode are central themes of two papers; a bakeable electronographic plate may still be required, however, despite its inability to match the large gain conferred by the conventional developing of a photographic plate. Image intensification is a fruitful subject at the moment and has received much attention; the television camera tube, on which so much effort has alroady been expended, did not figure so prominently, but infra-red and ultra-violet versions wore described. Nuclear physicists are extending the versatility of scintillation counters, as several papers show, and further progress can be expected, based on applying techniques developed for other devices.

One or two laboratories surveyed their own work over the past fow years, but review papers were otherwise absent; their inclusion in any symposium is a gamble for they may turn out to be more catalogues or to be insufficiently critical. But two or three good reviews here would have improved an already impressive and roadable report.

J. R. TILlman

\section{Diseases of Turfgrasses}

By Prof. Houston B. Couch. (Reinhold Books in A.gricultural Sciences.) Pp. xiii +289 . (Now York: Roinhold Publishing Corporation; London: Chapman and Hall, Ltd., 1962.) 80s. not.

$\mathrm{T}$ HE production and maintenance of high-quality grass turf, whether for ornamont or recreation, requires skilled managomont which involves effective control of diseases affecting turf grasses. A comprehonsive troatmont of this specialized topic would certainly be welcomed by turf specialists and plant pathologists; it is disappointing, therefore, to find that Prof. Couch's book does not fulfil the promise of its title.

The main text of the book occupies 180 pages and is divided into four chapters, the first of which deals briefly and in very general terms with the nature and causes of disease in plants. Chaptor 2 (124 pp.) is concerned with fungal diseases. These are well deseribed and the control practices (where any are available) are cloarly oxplained. The covorage on fungal diseases is certainly comprehensive and includes many diseases (for example, those affecting inflorescences, such as smuts and orgot) which might woll have been omitted. Indeed, their inclusion only serves to exaggerate the omissions referred to below. The third chapter deals concisely with nematodes, and the main text concludes with a short chapter on the fundamentals of disease control.

Two notable omissions from this book are physiological and virus diseases. Their exclusion can scarcely be justified in a work which claims to be comprehensive. To be told (p. 5) that physiological diseases are already woll covered in standard works on turf-grass management will searcely satisfy the plant pathologist, particularly when no specific references to sources of information are given. Equally the omission of virus diseases, apparently on the grounds that "information concorning them is not yot sufficient to evaluate properly their importance", is scarcoly acceptable. The same might be said of a great many of the fungel diseases described. 'The omission of virus diseases is all the more serious because recent work is showing that they may, in fact, be seriously domaging in agricultural swards; presumably they may be equally important in sports turf and lawns. Tho inclusion in this book of the symptoms, host-ranges and mode of transmission of the many grass viruses now known would have been most valuable if only in directing the attention of turf specialists to this group of diseases.

More than a third of the book is devoted to five appondix tables. Apart from the first (which is a short list of fung icides and nematocides), these constitute a particularly clear index of diseases and host species cross-referenced under their common and technical names. Certainly in this 100-page appendix the reader will have no difficulty in locating the items of information contained in the other 180 perges.

Eulis Griffiths

\section{The Morphology of Pteridophytes}

The Structure of Ferns and Allied Plants. By Dr. K. R. Sporne. Pp. 192. (London: Hutchinson University Library, 1962.) 12s. $6 d$. net.

THIS condensed but clear account of the morphology of the pteridophytes is evidently aimed primarily at an undergraduate public. Available at a most reasonable cost, it will suroly be deservedly popular as a student text. An excellent feature of this book is the attention directed to the integration of the results of modern re. search with classical morphology. Not only are more obvious discoveries like Stylites described, but also recent developments in all aspects of the subject are included. Rather more than half the ninety items included in the bibliography were first published since 1945 .

Great pains have evidently been taken over the production of the beautifully drawn figures, which are a joy to study. Nevertheless, one must regret that it has beon found necessary to overcrowd the illustrations on certain of the figures (for example, Figs. 14-17), so as to confuse the cye, and to over-reduce certain of the illustrations (for example, Figs. $12 A, 16 E$, and 17A) to such a degree that their evident quality is obscured. One appreciates with approval the intention to keep the price of this book as low as possible, but it is a pity that a larger page-size could not have been used.

Errors appear to be commendably few. There is an unfortunate misprint on the fourth line of p. 166, where Phyllitis is intended but Athyrium is printed, which may seriously mislead the unwary. It is not true that there are eleven species of Equisetum in the British flora, and Phylloglossum drummondii occurs also in south-western Australia, but these are small blemishes in an admirable text. This book is a valuable addition to the botanical literature, and is most warmly recommonded.

J. D. Lovrs 